\title{
THE EFFECT OF LOCALLY-GENERATED REVENUE, INVESTMENT, AND EDUCATION ON LABOR ABSORPTION AND PER CAPITA INCOME IN REGENCIES / CITIES OF BALI PROVINCE, INDONESIA
}

\author{
Setiawan A.A.S. Intan Prativi ${ }^{\star}$, Yuliarmi Ni Nyoman, Marhaeni A.A.I.N. \\ Study Program of Economic Development, Faculty of Economics and Business, \\ University of Udayana, Bali, Indonesia \\ *E-mail: aasgintanprativis@gmail.com
}

\begin{abstract}
Inequality between regencies/cities in Bali Province reflects that there is uneven welfare. This study aims to analyze: (1) The effect of locally-generated revenue, education, and investment on labor absorption in regencies/cities in Bali Province, (2) The effect of locallygenerated revenue, education, investment, and labor absorption on per capita income in regencies/cites in Bali Province, (3) The indirect effect of locally-generated revenue, education, and investment on per capita income through labor absorption in regencies/cities in Bali Province, (4) Differences in per capita income between development areas in Bali Province. The analysis technique used is path analysis and ANOVA, the number of observations in this study is 72 observation points which are secondary data. The results showed that the locally-generated revenue and investment had a positive and significant effect on labor absorption, while education has an effect but is not significant on labor absorption. the locally-generated revenue, education, and investment have a positive and significant effect on per capita income, while labor absorption does not affect the per capita income. Per capita income in the development area of East Bali, North Bali, and South Bali has heterogeneous or different variations. The South Bali development area has a higher per capita income than the North Bali and East Bali development areas.
\end{abstract}

\section{KEY WORDS}

Locally-generated revenue, education, investment, labor absorption, per capita income.

Economic development is a process of increasing total income and income per capita by taking into account population growth and accompanied by fundamental changes in the economic structure of a country (Sadono, 1985:13). Differences in income reflect differences in quality of life; rich countries (reflected by high income per capita) have a better quality of life compared to poor countries (Mankiw, 2006:46). Per capita income can also be used to compare the welfare or standard of living in a country or in an area year after year. By making such comparisons, it can be observed whether the welfare of the people in an area has on average increased (Todaro, 2000: 183).

The per capita income in regencies/cities in Bali Province tends to increase in the last 3 years. Badung Regency per capita income is the highest and is above the average of the Bali Province, which was 51,377 million Rupiah. While the lowest per capita income was in Bangli Regency, which was 18,327.2 million Rupiah and was below the average per capita income of Bali Province. This shows that there are still disparities in the regency / city level in Bali Province. Per capita income is a measure of public welfare. Differences in public welfare between regions can cause inequality. Wilayah (Ali, et al, 2013). Inequality between regions has been the main focus in government and community policy and society until now (Irawan, 2015).

One of the goals in economic development is the provision of sufficient employment to pursue the growth of the labor force, whose growth is faster than the growth of employment opportunities. The main problem in employment in Indonesia is on employment opportunities. The imbalance between the increase in the working-age population and the availability of employment opportunities will cause a gap called unemployment (Campolieti, et al, 2014). In the Bali Province, there are still disparities between regions in employment. This must be 
immediately addressed by the local government to anticipate unemployment and be able to increase income per capita in the local area.

The authority of the regional government through regional autonomy is expected to encourage the emergence of economic activity and economic growth in the regions which in turn can create new jobs and be able to increase employment (Stewart, 1994). To finance regional development, one of the capitals used comes from the locally-generated revenue. High labor absorption in developed countries is supported by the quality of its human resources. Developed and large countries which of course are supported by adequate quality education for its citizens ( $\mathrm{Wu}, 2018)$. The higher the education, the more dominant the employment status in the labor market (Lavrinovicha, et al., 2015).

In addition to capital from the internal government, assistance from outside the region is also needed to increase labor absorption and income per capita, one of which is an investment. Investment activities enable a community to continuously increase economic activities and employment opportunities, increase national income and the level of prosperity (Sukirno, 2001:367).

Based on the research background described, the purpose of this study is to analyze: (1) The effect of locally-generated revenue, education, and investment on labor absorption in regencies/cities in Bali Province, (2) The effect of locally-generated revenue, education, investment, and labor absorption on per capita income in regencies/cites in Bali Province, (3) The indirect effect of locally-generated revenue, education, and investment on per capita income through labor absorption in regencies/ cities in Bali Province, (4) Differences in per capita income between development areas in Bali Province.

\section{THEORETICAL REVIEW}

Per capita income is the average income of a population in a country. Per capita income can be used to compare the welfare or standard of living of a country from year to year (Sofyan, 2011). Sukirno (2004: 28) states that one component of national income that is always calculated is the income per capita, namely the average income of a population in a country or region at a certain time. The value is obtained by dividing the value of the Gross Regional Domestic Product (GRDP) in a given year by the total population in that year or known as regional income per capita or GRDP per capita. Therefore, the population is a denominator of income per capita in an area.

According to Suparmoko (2002: 42), labor is a population of working age or the total population in a country producing goods or services, workers of working age that are between 15-64 years. Job opportunities are the number of people who can be accommodated to work in a company. Labor absorption is the acceptance of workers to carry out tasks or obligations manifested in the increase in employee (Kuncoro, 2002: 45) The more workers, the per capita income in the area will also increase.

Education comes from the word pedagogi (education) which comes from the Greek language. Pedagogi and pedagogia consist of two words namely paedos (children) and agoge (guiding). It can be concluded that education is one aspect of developing quality human resources so that they can improve their abilities, and be able to absorb new technology (Suryapermana, et al, 2017:4). According to human capital theory, education influences economic growth through increasing employee skills and productivity. A high level of education will increase the employment of experts, which in turn will increase income per capita.

Investment is an important part of economic development, especially in efforts to increase economic growth (Linblad, 2015). Through investment, various production facilities will be available, which can be optimized in producing outputs and added value so that it will increase economic growth. Investment activities are important indicators that also determine the sustainability and success of economic development. Increasing investment will absorb labor through optimal production methods (Putra, 2012). 


\section{METHODS OF RESEARCH}

The location of this research is in the regencies/cities of Bali Province, because there is a disparity per capita income and labor absorption between regencies/cities in Bali Province. The focus of this study is on the effect of locally- generated revenue, education, and investment on labor absorption and per capita income in regencies/cities in Bali Province. This research uses secondary data. The data is taken from the Central Bureau of Statistics of Bali Province and other supporting literature about the object of research. The number of observations in this study was obtained by multiplying the year of observation which is 8 years from 2010 to 2017 with the number of regencies/cities in the Bali Province, which is 9 regencies/cities, the number of observations obtained in this study was 72 observation points.

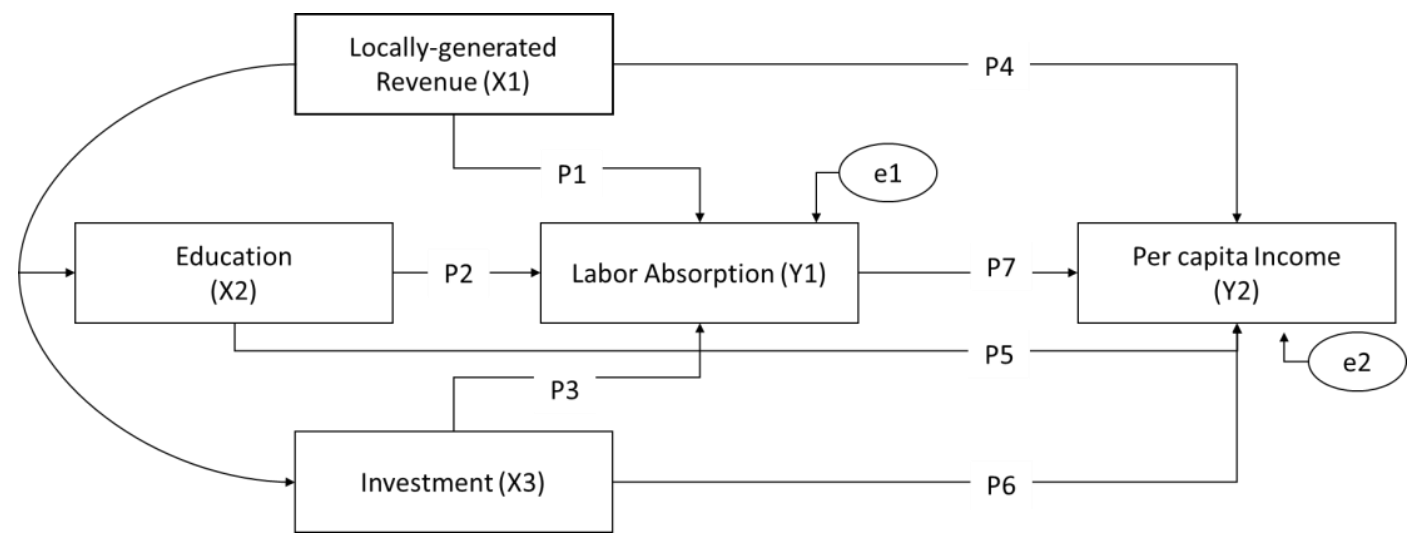

Figure 1 - Path Analysis Model the Effect of Locally-generated Revenue, Education, and Investment on Labor Absorption and Per capita Income

The method used in this research is the path analysis method. Path analysis is an extension of the application of multiple linear regression analysis, to estimate the causality relationship between variables (causal models) that have been predetermined based on the theory (Utama, 2012: 159).

Figure 1, explains the direct effect of locally-generated revenue on labor absorption by the path coefficient $\mathrm{P} 1$, education towards labor absorption is designated with $\mathrm{P} 2$, investment toward labor absorption is designated with P3, the locally-generated revenue to per capita income is designated with P4, education against per capita income is designated with P5, investment against per capita income is designated with P6, and labor absorption of income per capita appointed by P7.

Arrows e1 towards the labor absorption variable $\left(\mathrm{Y}_{1}\right)$ expresses the overall variance of labor absorption $\left(Y_{1}\right)$ which is not expressed from locally-generated revenue $\left(X_{1}\right)$, education $\left(\mathrm{X}_{2}\right)$, and investment $\left(\mathrm{X}_{3}\right)$. The e2 arrow to per capita income $\left(\mathrm{Y}_{2}\right)$ shows the number of per capita income variances that are not expressed by locally-generated revenue $\left(X_{1}\right)$, education $\left(\mathrm{X}_{2}\right)$, investment $\left(\mathrm{X}_{3}\right)$, and labor absorption $\left(\mathrm{Y}_{1}\right)$. The variable sub structural equation:

$$
\begin{aligned}
& Y_{1}=b_{1} X_{1}+b_{2} X_{2}+b_{3} X_{3}+e_{1} \\
& Y_{2}=b_{4} X_{1}+b_{5} X_{2}+b_{6} X_{3}+b_{7} Y_{1}+e_{2}
\end{aligned}
$$

Where: $Y_{1}=$ Labor absorption; $Y_{2}=$ Income per capita; $b_{1} b_{7}=$ Regression coefficient; $X_{1}=$ Locally-generated revenue; $X_{2}=$ Education; $X_{3}=$ Investment; $e=$ Confounding variable.

Analysis of variance is a statistical technique used to decide whether samples from populations have the same mean (Yamin and Kurniawan, 2014: 59). The method used in this study is the analysis of variance with one factor (one-way ANOVA). This method is used to compare whether there are differences or average similarities between three or more groups of data for a particular category. 


\section{RESULTS AND DISCUSSION}

Bali Province consists of 9 regencies/cities. There are the regions of Jembrana, Tabanan, Badung, Gianyar, Klungkung, Bangli, Karangasem, Buleleng, and Denpasar City. per capita income and labor absorption in the regencies/cities of Bali experience disparities, the same thing is experienced by locally-generated revenue, education, and investment in regencies/cities of Bali Province. Bali Province is divided into three development areas, namely North Bali, South Bali, and East Bali. The North Bali development area consists of Buleleng and Jembrana. The South Bali development area consists of Badung, Gianyar, Tabanan, and Denpasar. Meanwhile, the development area of East Bali consists of Klungkung, Karangasem, and Bangli.

The standard error of $\mathrm{e} 1$ is 0,663 and $\mathrm{e} 2$ is 0,531 . the coefficient of total determination of the standard error obtained $R^{2} m=0.88$, which means that 88 percent of the locallygenerated revenue, education level, investment, labor absorption and per capita income can be explained by the model, while the remaining 12 percent is explained by other variables not contained in the model.

Table 1 - Coefficient Table: the effect of $X_{1}, X_{2}, X_{3}$, to $Y_{1}$

\begin{tabular}{|c|c|c|c|c|c|c|}
\hline Model & Unstandardized Coefficients & \multicolumn{1}{c}{ Std. Error } & Standardized Coefficient Beta & $\mathrm{t}$ & $\mathrm{p}$-value & Explanation \\
\hline $\mathrm{X}_{1} \rightarrow \mathrm{Y}_{1}$ & 0,184 & 0,046 & 0,491 & 4,031 & 0,000 & Significant \\
\hline $\mathrm{X}_{2} \rightarrow \mathrm{Y}_{1}$ & 0,110 & 0,234 & 0,287 & 0,471 & 0,639 & Not Significant \\
\hline $\mathrm{X}_{3} \rightarrow \mathrm{Y}_{1}$ & 0,077 & 0,030 & 0,238 & 2,625 & 0,011 & Significant \\
\hline
\end{tabular}

Source: Data analysis by using SPSS (2020).

Based on the results of the study (Table 1) shows that the locally-generated revenue has a positive and significant effect on labor absorption with a standardized coefficient beta of 0.491 and a significance value of $0.000<0.05$, it means an increase of 1 million Rupiah in locally generated revenue will increase labor absorption by 0.491 or 49.1 percent, assuming other variables are considered constant. This can occur because when the locally-generated revenue increases each year, the locally-generated revenue can be utilized for the improvement and development of new infrastructure.

Especially the infrastructure that serves to increase employment opportunities so as to create a variety of new jobs that will later increase labor absorption in the area. The results of this study are in line with the results of the study by Pangastuti (2015) which states that the locally-generated revenue has a positive effect on employment in the Central Java Province.

Based on the results of the study (Table 1), education has no effect on labor absorption with a standardized coefficient beta of 0.051 and a significance value of $0.639>0.05$, which means that every 1year increase in education will have not affect labor absorption. the results of this study are in line with the results of research by Sihombing (2017), which states that the level of education has a positive but not significant effect on labor absorption in Medan. Purnami (2015) states that an increasing number of education graduates can have a positive influence or even a negative influence. It will be positive if the increase in education graduates is balanced with employment opportunities for them. It would be negative if only the graduates increased, but the available jobs did not increase or even decrease. Samiullah (2014) states that the level of education has a positive and not significant effect on employment in Pakistan.

Based on the results of the study (Table 1), show that investment has a positive and significant effect on labor absorption with a standardized coefficient beta of 0.287 and a significance value of $0.011<0.05$, which means an increase 1 million Rupiah in investment will increase labor absorption by 0.287 or 28.7 percent. the results of this study are in line with research from Taufik, et al, (2014) which states that investment has a positive and significant effect on labor absorption in the Province of East Kalimantan. Matthew \& Johnson (2014) revealed that foreign investment has a significant effect on employment in Nigeria. The same thing was expressed by Irpan, et al, (2016) that, foreign investment has a 
significant effect on employment in Malaysia. Dixit (1997) revealed that investment has a positive and significant effect on employment.

Table 2 - Coefficient Table: the effect of $X_{1}, X_{2}, X_{3}, Y_{1}$ to $Y_{2}$

\begin{tabular}{|c|c|c|c|c|c|c|}
\hline \multicolumn{1}{|c|}{ Model } & Unstandardized Coefficients & \multicolumn{1}{c}{ Std. Error } & \multicolumn{1}{c|}{ Standardized Coefficient Beta } & \multicolumn{1}{c|}{ p-value } & Explanation \\
\hline $\mathrm{X}_{1} \rightarrow \mathrm{Y}_{2}$ & 0,204 & 0,031 & 0,724 & 6,617 & 0,000 & Significant \\
\hline $\mathrm{X}_{2} \rightarrow \mathrm{Y}_{2}$ & 0,390 & 0,142 & 0,724 & 2,742 & 0,008 & Significant \\
\hline $\mathrm{X}_{3} \rightarrow \mathrm{Y}_{2}$ & 0,048 & 0,019 & 0,234 & 2,536 & 0,014 & Significant \\
\hline $\mathrm{Y}_{1} \rightarrow \mathrm{Y}_{2}$ & $-0,258$ & 0,073 & $-0,343$ & $-3,511$ & 0,001 & Not Significant \\
\hline
\end{tabular}

Source: Data analysis by using SPSS (2020).

Based on the results of the study (Table 2), locally-generated revenue has a positive and significant effect on per capita income with a standardized coefficient beta of 0.724 and a significance value of $0,000<0.05$, which means an increase of 1 million Rupiah in locallygenerated revenue will increase per capita income by 0.724 or 72.4 percent, assuming other variables are considered constant. This is in line with research from Sumardi (2015) which states that locally-generated revenue has a positive and significant effect on per capita income in regencies/cities in Bali Province Province. Jayanti (2013) also states that locallygenerated revenue has a positive and significant effect on per capita income in the Regency and City of Central Java Province.

Based on the result of the study (Table 2), education has a positive and significant effect on per capita income with a standardized coefficient beta of 0.238 and a significance value of $0.008<0.05$, which means that every 1 year increase in education will increase per capita income by 0.238 or 23.8 percent, assuming other variables are considered constant. This result in line with the research by Viracheat and Dash (2011), which states that education has a positive and significant effect on per capita income in Cambodia. Syamsurijjal (2008) also states that education has a positive and significant effect on per capita income in South Sumatera. The higher the level of community education in an area, the higher the level of skills and expertise possessed by the population in the region, so that overall productivity is high.

Based on the results of the study (Table 2) which shows a positive and significant relationship between investment and per capita income with a standardized coefficient beta of 0.234 and a significance value of $0.014<0.05$, that means an increase of 1 million Rupiah in investment will increase per capita income by 0.234 or 23.4 percent, assuming other variables are considered constant. The results of this study are in line with Sharma (2018) which states that investment has a positive and significant effect on per capita income. Hakizimana (2015) also states that Foreign Direct Investment (FDI) has a positive and significant effect on per capita income in Rwanda. Makki and Somwaru (2002) state that FDI has a positive and significant effect on per capita income in developing countries.

The labor absorption does not affect per capita income, based on the result of the study (Table 2). The standardized coefficient beta value is -0.334 and the significance value of $0.001<0.05$, that means an increase of 1 thousand people on labor absorption does not affect the income per capita, assuming other variables are considered constant. It is caused by the rate of population growth greater than the rate of employee growth so that the labor absorption does not affect the per capita income in regencies and cities of Bali Province. This result in line with what was published by Bank Indonesia which stated that there was a decrease in labor in the second quarter of 2010 in the formal sector. The results of the Business Activity Survey (SKDU) in the third quarter of 2013 showed a decrease in labor use compared to the previous quarter. Survey values below zero indicate that there is a decrease in the number of employees.

Because the labor absorption does not affect per capita income, the labor absorption is not a variable that mediates the effect of locally-generated income, education level and investment on per capita income. Therefore, there is no need to do a Sobel Test.

Differences in per capita income between regions can occur because there are differences in the amount of locally-generated revenue in each regency/city and differences 
in the amount of foreign and domestic investment in each region. The difference in per capita income between development areas in Bali Province can be seen in Table 3.

Table 3 - ANOVA Result

Per Capita Income

\begin{tabular}{|l|l|l|l|l|l|}
\hline $\mathrm{n} / \mathrm{n}$ & Sum of Squares & $\mathrm{df}$ & Mean Square & $\mathrm{F}$ & Sig. \\
\hline Between Groups & 28695.042 & 2 & 14347.521 & 122.637 & .000 \\
Within Groups & 2456.835 & 21 & 116.992 & & \\
Total & 31151.877 & 23 & & & \\
\hline
\end{tabular}

Source: Data analysis by using SPSS (2020).

Table 3 shows that per capita income in development area of Bali Province has a significance value of $0,000<0.05$ (alpha value), this proves that there are different variations in per capita income between the development areas of North Bali, South Bali and East Bali. For this reason, it is continued with the post hoc test analysis in Table 4.

Table 4 - Post Hoc Test Result

Dependent Variable: Per Capita Income

\begin{tabular}{|c|c|c|c|c|c|c|c|}
\hline \multirow{2}{*}{$\mathrm{n} / \mathrm{n}$} & \multirow{2}{*}{ (I) Wilayah } & \multirow{2}{*}{ (J) Wilayah } & \multirow{2}{*}{ Mean Difference (I-J) } & \multirow{2}{*}{ Std. Error } & \multirow{2}{*}{ Sig. } & \multicolumn{2}{|c|}{ 95\% Confidence Interval } \\
\hline & & & & & & Lower Bound & Upper Bound \\
\hline \multirow{6}{*}{ Bonferroni } & \multirow{2}{*}{1} & 2 & -77.230875 & 5.408146 & .000 & -91.29935 & -63.16240 \\
\hline & & 3 & -8.501250 & 5.408146 & .393 & -22.56973 & 5.56723 \\
\hline & \multirow{2}{*}{2} & 1 & 77.230875 & 5.408146 & .000 & 63.16240 & 91.29935 \\
\hline & & 3 & 68.729625 & 5.408146 & .000 & 54.66115 & 82.79810 \\
\hline & \multirow{2}{*}{3} & 1 & 8.501250 & 5.408146 & .393 & -5.56723 & 22.56973 \\
\hline & & 2 & -68.729625 & 5.408146 & .000 & -82.79810 & -54.66115 \\
\hline \multirow{6}{*}{ Games-Howell } & \multirow{2}{*}{1} & 2 & -77.230875 & 6.006518 & .000 & -93.77873 & -60.68302 \\
\hline & & 3 & -8.501250 & 3.719435 & .092 & -18.25394 & 1.25144 \\
\hline & \multirow[b]{2}{*}{2} & 1 & 77.230875 & 6.006518 & .000 & 60.68302 & 93.77873 \\
\hline & & 3 & 68.729625 & 6.150745 & .000 & 51.97541 & 85.48384 \\
\hline & \multirow{2}{*}{3} & 1 & 8.501250 & 3.719435 & .092 & -1.25144 & 18.25394 \\
\hline & & 2 & -68.729625 & 6.150745 & .000 & -85.48384 & -51.97541 \\
\hline
\end{tabular}

* The mean difference is significant at the 0.05 level. Source: Data analysis by using SPSS (2020).

According to the results of the post hoc tests in Table 4 shows that the development area of South Bali is different from the development area of North Bali and East Bali. This can occur because the per capita income of the South Bali development area is much higher compared to the per capita income of the North Bali and East Bali development areas. The South Bali development area has an average per capita income higher than other development areas because of the regencies/cities in this region are metropolitan areas. South Bali's development area is the center of industrialization and tourism so that, the locally-generated income and the investment amounts are higher compared to other regions.

Besides, regional disparities cause differences in per capita regency/city income in Bali Province. The disparity between disadvantaged and developed regions is a consequence of changes in the economic structure and the process of industrialization, where private and government investment (infrastructure and institutions) tend to be concentrated in developed regions. As a result, developed regions experience faster growth (Valley, 2008).

\section{CONCLUSION}

Based on the results of the discussion and analysis, it can be summarized as follows.

- Locally-generated revenue and investment have a positive and significant effect on labor absorption in the regencies/cities of Bali Province, while education has a positive and not significant effect on labor absorption in the regencies/cities of Bali Province; 
- Locally-generated revenue, education, and investment have a direct effect on per capita income in the regencies/cities of Bali Province;

- Locally-generated revenue, education, and investment do not have an indirect effect on per capita income through employment in the regencies/cities of Bali Province;

- Per capita income in the development regions of East Bali, North Bali, and South Bali has heterogeneous or different variations. The South Bali development area has a higher per capita income than the North Bali and East Bali development area.

From some conclusion obtained, should be submitted suggestion as follow.

- Each regency/city government of Bali Province should pay more attention to the education sector which is one of human capital to improve the quality of its human resources by building certain facilities and infrastructure so that the level of education is able to support labor absorption and improve the welfare;

- The regency/city government of Bali Province must pay more attention to the rate of population growth, and build infrastructure that supports the increase in labor absorption in order to be able to fight unemployment, increase income per capita and improve welfare;

- The regency/city regional government of Bali Province must explore the potential of their respective regions so that existing regional finances can be used at the right potential to support the welfare.

\section{REFERENCES}

1. Ali, Hasnah, Er, A.C., Ahmad, A.R., Lyndon, N., Ahmad, Sanep. 2013. Analysis of the Impact of Foreign Investment on Regional Disparities: A Case of Malaysia. Asian Sosial Science. Vol 9. No. 14.

2. Campolieti, Michele. et al. 2014. A New Look at Variation in Employment Growth in Canada: The Role of Industry, Provincial, National and External Factors. Journal of Economic Dynamics and Control, Vol 41.

3. Caraka, Rezzy E. 2019. Pemodelan Regresi Panel Pada Data Pendapatan Asli Daerah (PAD) Terhadap Dana Alokasi Umum (DAU). Jurnal Ekonomi Kuantitatif Terapan. Vol.12 No.1

4. Dixit, Avenash. 1997. Investment and Employment Dynamics in The Short and The Long Run. Oxford Economics Papers, Vol.49, No.1

5. Hakizimana, J. 2015. The Relationship Between Foreign Direct Investment (FDI) and GDP Per Capita in Rwanda. SSRN Electronic Journal.

6. Hofman, B., Fitriani, F., \& Kaiser, K. 2005. Unity in Diversity? The Creation of New Local Governments in a Decentralising Indonesia. Bulletin of Indonesian Economic Studies. Vol 41. No.1.

7. Irawan, Andi. 2015. Regional Income Disparities in Indonesia: Measurements, Convergence Process, and Decentralisation. Bulletin of Indonesian Economic Studies, Vol 51 No. 1.

8. Irpan, H. M., Saad, R. M., Nor, Abu Hassan., Noor Abd., \& Ibrahim N. 2016. Impact of Foreign Direct Investment on The Unemployment Rate in Malaysia. Journal of Physics: Conference Series 710.

9. Jayanti, Widya. 2013. Pengaruh Belanja Modal and Pendapatan Asli Daerah (PAD) Terhadap Pendapatan Perkapita. Universitas Muhammadiyah Surakarta.

10. Kuncoro, Haryo. 2002. Upah Sistem Bagi Hasil and Penyerapan Tenaga Kerja. Jurnal Ekonomi Pembangunan. Vol. 7 No. 1.

11. Lavrinovicha, I., Lavrinenko, O., Treinovskis, J. T. 2015. Influence of Education on Unemployment Rate and Incomes of Residents. Procedia - Social and Behavioral Sciences. 174

12. Lindblad, J. Thomas. 2015. Foreign Direct Investment in Indonesia: Fifty Years of Discourse. Bulletin of Indonesian Economic Studies, Vol. 51. No.2. 
13. Makki, Shiva S \& Somwaru, Agapi. 2002. Impact of Foreign Direct Investment and Trade on Economic Growth. Journal of Economic Literature Classification numbers F10, F21, O1, 040 .

14. Mankiw, N. Gregory. 2006. Teori Makroekonomi Edisi Keenam. Terjemahan. Jakarta: Penerbit Erlangga.

15. Matthew, Okoro, H. \& Johnson, A. Atan. 2014. Impact of Foreign Direct Investment on Employment Generation in Nigeria: A Statistical Investigation. IOSR Journal of Business and Management. Vol. 16, Issue 3. Ver II.

16. Pangastuti, Yuli. 2015. Analisis Faktor - Faktor yang Mempengaruhi Penyerapan Tenaga Kerja di Provinsi Jawa Tengah. Economics Development Analysis Journa.I Vol 4. No.2.

17. Purnami, I. 2005. Pengaruh Tingkat Pendidikan and Upah Minimum Kabupaten/Kota (UMK) Terhadap Penyerapan Tenaga Kerja di Provinsis Jawa Barat Tahun 2010-2013. Universitas Islam Negeri Syarif Hidayatullah Jakarta.

18. Putra, Riky Eka. 2012. Pengaruh Nilai Investasi, Nilai Upah, and Nilai Produksi Terhadap Penyerapan Tenaga Kerja Pada Industri Mebel Di Kecamatan Pedurungan Kota Semarang. Economics Development Analysis Journal. EDAJ, Vol 1. No. 2.

19. Samiullah, 2014. Relationship between Education, Health and Employment A Time Series Analysis of Parkistan. Journal of Economics and Sustainable Development. Vol.5, No.7.

20. Sihombing, Fransisca Natalia. 2017. Kontribusi Tingkat Pendidikan and Upah Minimum Terhadap Penyerapan Tenaga Kerja di Kota Medan Tahun 2012-2015. Jurnal Pembangunan Perkotaan. Vol. 5 No. 1.

21. Sofyan, Muhammad. 2011. Analisis Pengaruh Pendapatan Perkapita, Tingkat Suku Bunga, Jumlah Uang Beredar (M2) and Inflasi Terhadap Jumlah Tabungan di Indonesia. Jakarta.

22. Stewart, F., \& Ranis G., 1994. Decentralisation in Indonesia. Bulletin of Indonesian Economic Studies. Vol 30. No. 3.

23. Sukirno, Sadono. 2001. Pengantar Teori Mikro Ekonomi. Edisi Kedua. Jakarta: Rajawali Press.

24. Sukirno, Sadono. 2004. Pengantar Teori Makroekonomi. Jakarta: PT Raja Grafindo Persada.

25. Sumardi, Hamka. 2015. Analisis Pendapatan Asli Daerah, Dana Alokasi Umum, and Dana Alokasi Khusus Terhadap Pendapatan Perkapita Pada Kabupaten/Kota di Provinsi Bali. JURNAL AKSES. Vol.25. No.2.

26. Suparmoko, M. 2002. Ekonomi Publik, Untuk Keuangan and Pembangunan Daerah. Andi. Yogyakarta

27. Suryapermana, Nana., \& Imratun. 2017. Dasar-Dasar IImu Pendidikan: Cetakan Pertama. Banten: FTK Banten Press.

28. Taufik, M., Rochaida, Eny., \& Fitriadi. 2014. Pengaruh Investasi and Ekspor Terhadap Pertumbuhan Ekonomi Serta Penyerapan Tenaga Kerja Provinsi Kalimantan Timur. Jurnal Ekonomi Kuantitatif Terapan. Vol. 7 No. 2.

29. Todaro, Michael. P. 2000. Pembangunan Ekonomi di Dunia Ketiga. Edisi Ketujuh, Terjemahan Haris Munandar. Jakarta: Penerbit Erlangga

30. Utama, Suyana. 2012. Aplikasi Analisis Kuantitatif. Fakultas Ekonomi Universitas Udayana. Denpasar.

31. Valley D, Phillips A. 2008. Studies in Inequality of Income, and Consumption Function: Some Cross-Country Result. Journal of Political Economy. Vol 133 No.6.

32. Viracheat, In \& Dash, Tapas R. 2011. Growth of Higher Education and Its Relationship with Per capita Gross Domestic Product in Cambodia. International Journal of Business and Social Science. Vol. 2 No, 12.

33. Wu, Suci. 2018. 10 Negara dengan Sistem Pendidikan Terbaik di Dunia. IDN Times. https://www.idntimes.com/life/education/suci-wu-1/negara-dengan-sistem-pendidikanterbaik-di-dunia-c1c2/full

34. Yamin, Sofyan., \& Kurniawan, Heri. 2014. SPSS Complete Edisi 2. Jakarta Selatan: Salemba Infotek. 